\title{
Dispersed trees on smallholder farms enhance soil fertility in semi-arid Ethiopia
}

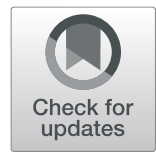

\author{
Yikunoamlak Gebrewahid ${ }^{1 *}$ (D), Kassa Teka², Tewolde-Berhan Gebre-Egziabhier ${ }^{3}$, Sara Tewolde-Berhan², \\ Emiru Birhane ${ }^{2,4}$, Gebru Eyasu $^{5}$ and Esayas Meresa ${ }^{5}$
}

\begin{abstract}
Introduction: Dispersed trees such as Oxytenanthera abyssinica (A. Rich.) and Dalbergia melanoxylon (Guill. \& Perr.) which are objectively maintained or planted on farmland provide a significant contribution to soil fertility improvement. However, there was no quantitative information on the level of soil nutrient additions of these trees to the soil system.

Methods: This study was conducted on the farmers' fields in Kafta Humera district, Tigray region (northern Ethiopia), where mature stands of $O$. abyssinica and D. melanoxylon trees exist. Radial distance-based soil sampling (under the canopy, near to canopy, and far from canopy) was adopted to quantify the role of these trees on soil fertility improvement. Soil parameters tested were soil reaction (pH), total nitrogen (TN), available phosphorus (AvP), electrical conductivity (EC), cation exchange capacity (CEC), and organic carbon (OC).

Results: There was a negative linear relationship between the radial distance of the $O$. abyssinica tree trunk and soil TN, OC, CEC, and AvP contents but not for pH. Similarly, negative linear relationship between distance from D. melanoxylon and TN, $\mathrm{OC}$, and AvP was obtained. The average total nitrogen (0.26\% and 0.13\%), available phosphorus (7.21 ppm and $6.37 \mathrm{ppm})$, and organic carbon (1.73\% and 1.02\%) contents were respectively higher under the tree canopies of $O$. abyssinica and $D$. melanoxylon compared with the adjacent open canopies. The amount of soil OC, TN, AvP, and CEC under O. abyssinica tree species was also significantly higher by $69 \%, 100 \%, 13 \%$, and $42 \%$ compared to that of D. melanoxylon tree species. However, the amount of EC and soil pH was significantly lower by $57 \%$ and $19 \%$, respectively.

Conclusion: In general, O. abyssinica and D. melanoxylon added a significant amount of nutrients to the soil. Thus, retaining these important tree species on farmland played a positive role in replenishing soil fertility for resource-constrained households so as to reduce chemical fertilizer amendments.
\end{abstract}

Keywords: Scattered tree, Oxytenanthera abyssinica, Dalbergia melanoxylon, Soil properties

\section{Introduction}

Soil nutrient degradation is considered as a major challenge in achieving food security and natural resource conservation in sub-Saharan Africa such as Ethiopia (Sanchez and Swaminathan 2005; Bationo et al. 2007). In Ethiopia, soil degradation is the most immediate environmental problem (Bishaw 2001). The loss of soil through erosion that deteriorates soil fertility, moisture storage capacity, and soil structure contributed to reduced agricultural productivity in the country (Bishaw 2001). Even though, there is no study conducted on the monetary value of soil loss in the country. A

\footnotetext{
*Correspondence: yikuno22@gmail.com; yikuno22@yahoo.com

${ }^{1}$ Humera Agricultural Research Center (HuARC), Tigray Agricultural Research

Institute (TARI), P.O. Box 62, Humera, Ethiopia

Full list of author information is available at the end of the article
}

study by Bationo et al. (2007) for the entire continent of Africa revealed that Africa loses US\$4 billion per year due to soil nutrient degradation. The problem is pervasive among mixed crop and livestock farming systems of the region where competing uses for crop residues such as livestock fodder or household fuel that do not sufficiently replenish the soil exist. Nutrient replacement using mineral fertilizers is a limited option for many smallholder farming households of the region. At only eight kilograms per hectare, the region has the lowest mineral fertilizer application rates in the world and concomitantly, much lower crop yields than achieved in other developing regions (Morris et al. 2007).

Hence, implementing agroforestry systems in resourcepoor farming households is considered to mitigate soil nutrient mining (Bishaw 2001; Gladwin et al. 2002). 
Integration of legume trees into agricultural systems, therefore, adds biologically fixed nitrogen and other agriculturally important nutrients to the soil (Rosenstock et al. 2014) in a way that complements the crops grown in association with the trees (Akinnifesi et al. 2010). These trees are also known to bring about changes in edaphic, micro-climatic, and other components of the ecosystem through bio recycling of mineral elements, environmental modifications (including thermal and moisture regime), and changes in floral and faunal composition (Shukla 2009).

There are numerous examples of traditional land-use practices that incorporate trees into agricultural crop fields on the same piece of land (Mosquera-Losada et al. 2009). Cultivating and use of trees and/or shrubs like Oxytenanthera abyssinica and Dalbergia melanoxylon together with crops and livestock is a long-standing tradition in many parts of Ethiopia such as Kafta Humera District in northern Ethiopia (Kamara and Haque 1992; Sisay and Mekonnen 2013). These trees have been either purposely planted or naturally grown on farmlands and left to stand to support agriculture (Ajake 2013; Aladi and John 2014) by reducing nutrient losses from erosion and leaching, increasing nutrient inputs through nitrogen fixation, and increasing biological activities by providing biomass and suitable microclimate (Ogunkunle and Awotoye 2010). Moreover, farmers in Kafta Humera District revealed that these trees provide firewood, timber (for local construction), medicine (bark, root, and leaves), bee forage, carving, and other benefits that are vital to the rural communities (Bein et al. 1996; Bekele-Tesemma 2007).

However, the contribution of these trees to soil fertility enhancement, regardless the farmers maintain these trees on their crop field, was not adequately studied. Hence, this study tried to quantify the effects of Oxytenanthera abyssinica and Dalbergia melanoxylon trees on soil properties following a distance gradient from the tree canopy.

\section{Materials and methods}

\section{Study area description}

The study was conducted at Adi-Goshu village in Kafta Humera district, Northern Ethiopia (Fig. 1). Geographically, the area lies between $36^{\circ} 27^{\prime} 4.70^{\prime \prime}-37^{\circ} 33^{\prime} 7.12^{\prime \prime} \mathrm{E}$ and $13^{\circ} 39^{\prime} 46.47^{\prime \prime}-14^{\circ} 26^{\prime} 34.87^{\prime \prime} \mathrm{N}$ within an altitudunal range of $499-1849 \mathrm{~m}$ above sea level. The area is classified in the semi-arid climate and is characterized by a mean annual rainfall of $609 \mathrm{~mm}$ in which the rainy season is from June to September. The mean maximum temperature varied between $32.3^{\circ} \mathrm{C}$ in August and $42.5^{\circ} \mathrm{C}$ in May, while the mean minimum temperature is between $17.8^{\circ} \mathrm{C}$ in January and $25.1{ }^{\circ} \mathrm{C}$ in April (Fig. 2). The major soil types found in the area are vertisols, cambisols, and luvisols. The area is also characterized by a mixed farming system which composed of annual crops, trees, and livestock. Sesame (Sesamum indicum), sorghum (Sorghum bicolor), and cotton (Gossypium) are the commonly grown cereal crops in the area. The common type of agroforestry practice noticed in the study area is parkland agroforestry that is known for retaining indigenous trees on farmlands (Gebrewahid et al. 2018). The dominant tree species grown on farmlands include Pterocarpus leucens, Oxytenanthera abyssinica, Ziziphus spinachristi, Dalbergia melanoxylon, and Combretum spp.

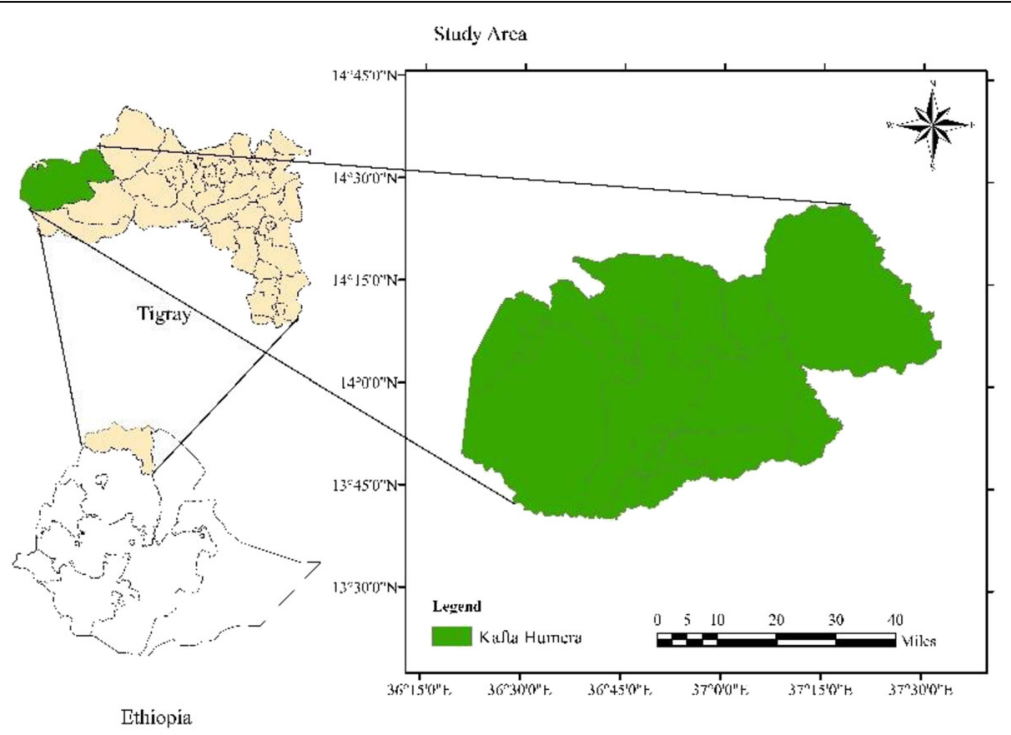

Fig. 1 Map showing location of study area 


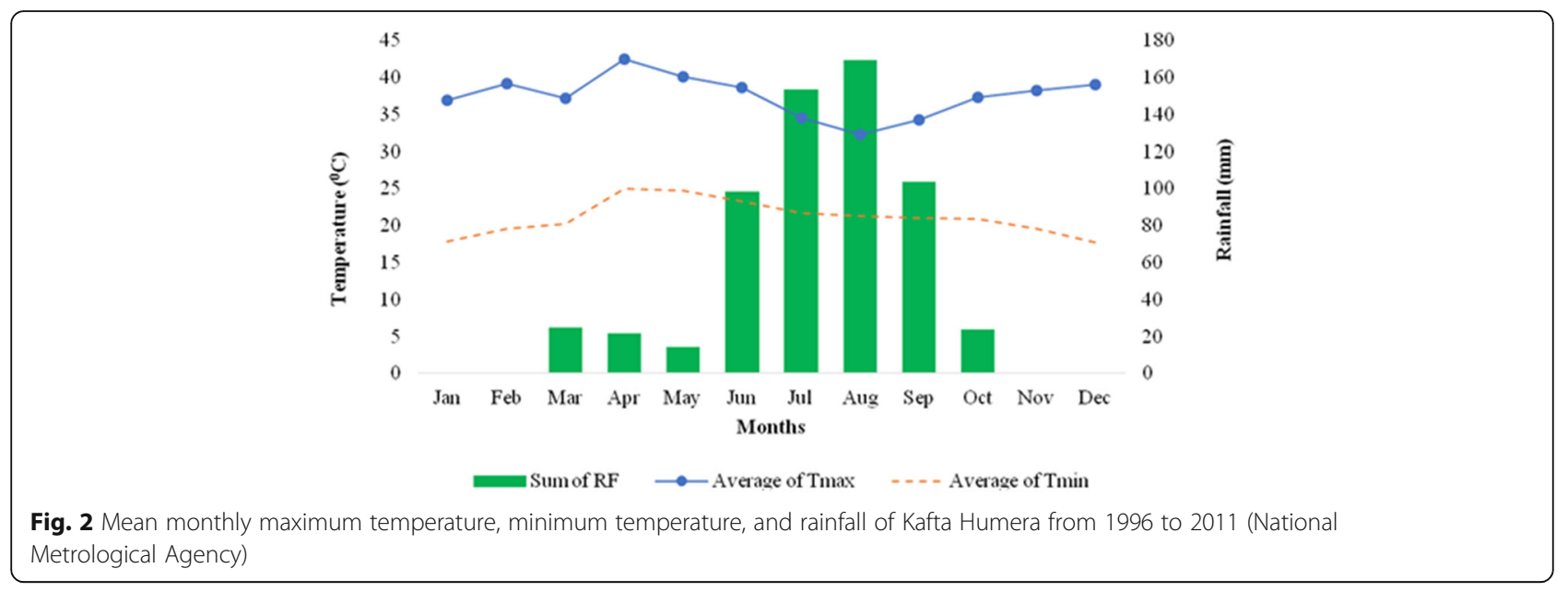

\section{Experimental design and field layout}

The study was carried out on farmers' fields to compare the soil fertility status under traditionally retained scattered Oxytenanthera abyssinica and Dalbergia melanoxylon trees against open farmland outside the canopy cover of each tree. Both species are native to Ethiopia, endemic to the site, and are well represented in this environment (Bein et al. 1996; Bekele-Tesemma 2007). To collect data on soil properties, 16 isolated and nearly identical trees of each species grown on similar site conditions were systematically selected based on diameter at breast height $(\mathrm{DBH})$, tree height $(\mathrm{TH})$, and crown diameter $(\mathrm{CR})$. Radial distance-based soil sampling (under the canopy, near to canopy, and far from canopy) was adopted. The three different radial distances were (i) the canopy radius under the tree $(1.7 \mathrm{~m}$ for Oxytenanthera abyssinica and $1.2 \mathrm{~m}$ for Dalbergia melanoxylon), (ii) canopy edge ( $3.1 \mathrm{~m}$ for Oxytenanthera abyssinica and $2.5 \mathrm{~m}$ for Dalbergia melanoxylon), and (iii) outer radius ( $14.5 \mathrm{~m}$ for Oxytenanthera abyssinica and $14.5 \mathrm{~m}$ for Dalbergia melanoxylon) following the procedure outlined in Pandey et al. (2000) and Gindaba et al. (2005). Generally, the design was $1 \times 3$ arrangements of treatments (three radius) in randomized complete block design replicated 16 times (16 scattered trees of each species). In total, 96 soil samples were collected (Fig. 3).

\section{Tree characteristics and distribution}

Oxytenanthera abyssinica is a woody perennial belonging to the family of Poaceae with unique characteristics (Wang 2006). It is a fast-growing and selfsustaining species once established (Bystriakova et al. 2004). In Ethiopia, Oxytenanthera abyssinica is well known as a multipurpose tree with different functions such as construction material, furniture, fence, handicraft, pulp and paper, edible shoots, and animal fodder (Bein et al. 1996; Bekele-Tesemma 2007). The leaves of Oxytenanthera abyssinica is blue-green, rounded base, long tip, and spiny, usually $15 \times 2.5 \mathrm{~cm}$ long but can reach up to $30 \times 5 \mathrm{~cm}$ (Bein et al. 1996; Bekele-Tesemma 2007).

Dalbergia melanoxylon is a small woody perennial which belongs to the family of Papilionoideae (Bein et al. 1996). In Tigray, the tree is also well known as a multipurpose tree with different functions such as firewood, timber (construction), carving, medicine (bark, roots, leaves), fodder (fruit, leaves), bee forage, nitrogen fixation, and walking sticks (Bekele-Tesemma 2007). The leave of Dalbergia melanoxylon is compound, having stalk length of $20 \mathrm{~cm}, 9-13$ leaflets, and rounded or notched tip. Both trees species shade their leaves during the dry season.

Canopy cover in agroforestry system is directly related to the degree of light and rainfall interception (Jackson 2000) that may affect soil physical properties such as soil temperature and moisture (Ritter et al. 2005). The sampled Oxytenanthera abyssinica tree had an average DBH, $\mathrm{TH}$, and $\mathrm{CR}$ of $7.8 \mathrm{~cm}, 4.9 \mathrm{~m}$, and $5.2 \mathrm{~m}$, respectively, whereas the sampled Dalbergia melanoxylon tree had $\mathrm{DBH}, \mathrm{TH}$, and CR of $17.6 \mathrm{~cm}, 5.5 \mathrm{~m}$, and $4.4 \mathrm{~m}$, respectively. The estimated age of Oxytenanthera abysinica and Dalbergia melanoxylon was $20-28$ and $35-45$ years old, respectively.

\section{Data collection}

A total of 96 composited soil samples were taken at a depth of $20 \mathrm{~cm}$ representing the topsoil as proposed in FAO (2006) and at three distances (radius) in four different directions (North, South, East, and West of each tree). The collected soil samples were analyzed for soil reaction $(\mathrm{pH})$, soil organic carbon (SOC), total nitrogen (TN), available phosphorus 


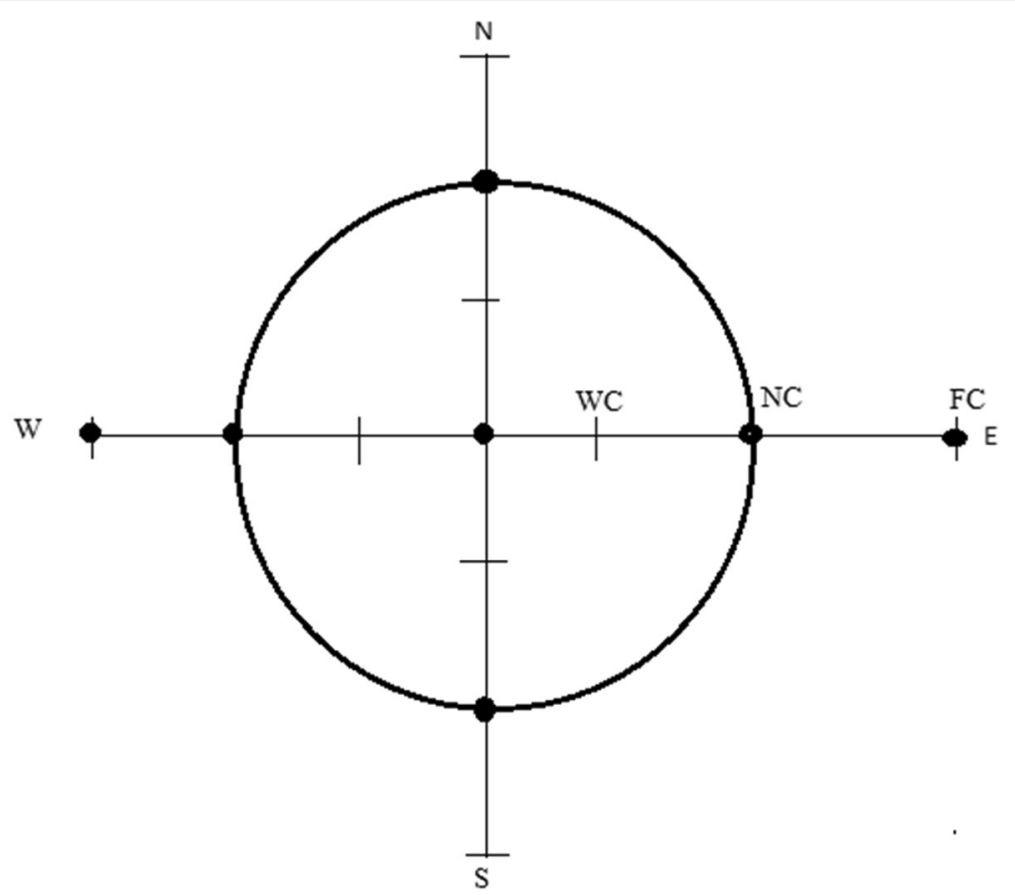

Fig. 3 Design of soil sampling from Oxytenanthera abyssinica and Dalbergia melanoxylon tree, where N is North, S is South, E is East, W is West, WC is under the canopy, NC is near to the canopy, and FC is far to the canopy

(AvP), electrical conductivity (EC), and cation exchange capacity (CEC).

\section{Soil laboratory analysis}

Prior to analysis, each composite soil sample was airdried and passed through a 2 -mm sieve for most of the selected soil properties and further sieved to pass through a $0.5-\mathrm{mm}$ sieve size for analysis of total nitrogen. Soil organic carbon (SOC) was analyzed using the Walkley-Black oxidation method (Chesworth 2008), total nitrogen (N) using the Kjeldhal method (Jackson 1958), available phosphorus (P) using the Olsen method (Olsen and Sommers 1982), pH using the potentiometer method (McLean 1982), electrical conductivity (EC), and cation exchange capacity (CEC) using the ammonium acetate method (Houba et al. 1989).

\section{Statistical analysis}

The impact of trees on soil properties was compared using one-way analysis of variance (ANOVA) following the linear model (GLM) procedure at $P<0.05$ with the help of $\mathrm{R}$ software for Window versions 3.4.3. Whenever statistical difference existed, it was subjected to Tukey's HSD test to separate the means. Two-sample $t$ test was also used to compare soil properties between tree species.

\section{Results}

Impact of Oxytenanthera abyssinica and Dalbergia melanoxylon on soil properties

Soil organic carbon (SOC)

In this study, the soil organic carbon content of abyssinica and D. melanoxylon ranged from 0.58 to $2.86 \%$ and 0.33 to $1.41 \%$, respectively, and was highly significantly $(P<0.001)$ affected by distance from the tree base. It was higher under the canopies of both tree species. All soil properties decreased with increasing distance from the base of the tree (Table 1).

\section{Total nitrogen (TN)}

Total nitrogen significantly $(P<0.001)$ decreased with increasing distance from each tree trunk base. It decreased from $0.26 \%$ at the smaller distance to $0.12 \%$ at the far distance of $O$. abyssinica and from $0.13 \%$ at the smaller distance to $0.07 \%$ at the far distance of $D$. melanoxylon (Table 1).

\section{Available phosphorus (AvP)}

The mean available phosphorus significantly decreased with increased distance from the tree base of both tree species. The AvP at the tree base of O. abyssinica and D. melanoxylon was higher by $7.21 \mathrm{ppm}$ and $6.37 \mathrm{ppm}$ respectively as compared to the open fields (Table 1). 
Table 1 OC, TN, AvP, EC, CEC, and pH under Oxytenanthera abyssinica and Dalbergia melanoxylon trees with different radii from trunk of the tree

\begin{tabular}{|c|c|c|c|c|c|c|c|c|}
\hline Tree & Radius from the tree $(\mathrm{m})$ & OC\% & TN\% & $A v P$ & EC & CEC & $\mathrm{pH}$ & C-to-N \\
\hline \multirow[t]{5}{*}{ Oxytenanthera abyssinica } & Under canopy & $1.73(0.16)^{a}$ & $0.26(0.01)^{a}$ & $7.21(0.20)^{a}$ & $0.07(0.01)$ & $55.74(1.35)^{\mathrm{a}}$ & $6.13(0.10)^{a}$ & $6.50(0.47)^{\mathrm{a}}$ \\
\hline & Near to canopy & $1.28(0.09)^{b}$ & $0.13(0.01)^{b}$ & $6.55(0.19)^{a}$ & $0.07(0.01)$ & $48.02(1.45)^{b}$ & $6.30(0.08)^{a b}$ & $12.10(2.10)^{b}$ \\
\hline & Far from canopy & $1.30(0.11)^{b}$ & $0.12(0.01)^{b}$ & $6.02(0.21)^{\mathrm{b}}$ & $0.08(0.01)$ & $45.02(2.18)^{b}$ & $6.56(0.09)^{\mathrm{b}}$ & $11.44(0.43)^{b}$ \\
\hline & $F$ value & 4.179 & 57.337 & 9.125 & 0.852 & 10.569 & 5.922 & 5.806 \\
\hline & $P$ value & * & $* * *$ & $* * *$ & 0.4333 & $* * *$ & $* *$ & $* *$ \\
\hline \multirow[t]{5}{*}{ Dalbergia melanoxylon } & Under canopy & $1.02(0.06)^{a}$ & $0.13(0.005)^{\mathrm{a}}$ & $6.37(0.28)^{a}$ & $0.11(0.01)$ & $39.27(3.20)$ & $7.29(0.14)$ & $7.74(0.5)$ \\
\hline & Near to canopy & $0.70(0.06)^{b}$ & $0.09(0.005)^{b}$ & $5.78(0.21)^{\mathrm{ab}}$ & $0.11(0.01)$ & $30.32(3.81)$ & $7.16(0.18)$ & $8.59(1.0)$ \\
\hline & Far from canopy & $0.65(0.05)^{b}$ & $0.07(0.004)^{c}$ & $5.32(0.17)^{\mathrm{b}}$ & $0.14(0.01)$ & $32.56(3.68)$ & $7.15(0.21)$ & $10.02(1.1)$ \\
\hline & $F$ value & 11.924 & 51.841 & 5.525 & 3.073 & 1.699 & 0.193 & 1.601 \\
\hline & $P$ value & $* * *$ & $* * *$ & $* *$ & 0.056 & 0.194 & 0.825 & 0.212 \\
\hline
\end{tabular}

Note: Rows with the same superscript letters are not significantly different at $P<0.05$. Standard error (SE) mean is shown in parenthesis, ${ }^{*}$ are given when $P$ values less than $0.05,{ }^{* *}$ are given when $P$ values less than 0.01 , and ${ }^{* * *}$ are given when $P$ values less than 0.001

OC \% organic carbon percent, Total N\% total nitrogen, Available $P(p p m)$ available phosphorus, EC (dS/m) electrical conductivity, CEC meq/100 g cation exchange capacity

\section{Soil electrical conductivity (EC)}

The analysis of variance revealed that soil EC was not significantly affected by distance from the tree base of both tree species (Table 1 ). It ranged from 0.02 to 0.14 $\mathrm{dS} / \mathrm{m}$ and 0.04 to $0.21 \mathrm{dS} / \mathrm{m}$ respectively for $O$. abyssinica and D. melanoxylon.

\section{Soil cation exchange capacity (CEC)}

CEC values were highly significantly $(P<0.001)$ affected by distance from the tree base in $O$. abyssinica but not significantly different in $D$. melanoxylon tree. The average cation exchange capacity values of soils for Oxytenanthera abysinica species were 55.74, 48.02 and $45.02 \mathrm{meq} / 100 \mathrm{~g}$ at $1.7 \mathrm{~m}, 3.1 \mathrm{~m}$ and $14.5 \mathrm{~m}$ far from the tree trunk respectively. These values decreased with increasing distance from Dalberigia melanoxylon tree base (Table 1).

\section{Soil reaction $(\mathrm{pH})$}

Soil $\mathrm{pH}$ significantly increased with increased distance from tree trunk for $O$. abyssinica (Table 1). It increased from 5 at the smaller distance to 7.02 at the far distance. However, the soil $\mathrm{pH}$ of $D$. melanoxylon was not significantly $(P=0.825)$ affected by distance.

\section{Carbon to nitrogen ratio (C:N)}

The concentration of soil organic carbon to soil nitrogen $(\mathrm{C}: \mathrm{N})$ ratio significantly increased with increasing distance from the tree trunk of both species (Table 1). The soil C:N ratio in surface soil ranged from 3.44 to 43 and 3.3 to 21 for $O$. abyssinica and D. melanoxylon, respectively.

\section{Comparable results between the trees on soil properties}

Except for the $\mathrm{C}: \mathrm{N}$ ratio, the concentration of soil nutrients on the studied species did not show significant variation $(P>0.05)$ along distance from each tree species (Table 2). However, Oxytenanthera abyssinica had significantly higher $(P<0.05) \mathrm{OC}, \mathrm{TN}, \mathrm{AvP}$, and CEC but lower EC and soil reaction (pH) compared with the Dalbergia melanoxylon (Table 2).

Table 2 Comparison on soil nutrient concentration between Oxytenanthera abyssinica and Dalbergia melanoxylon trees of under, near, and far to canopy

\begin{tabular}{lllllll}
\hline Radius from the tree $(\mathrm{m})$ & OC\% & TN\% & AvP & EC & CEC & pH \\
\hline Under canopy & $* * *$ & $* * *$ & $*$ & $* *$ & $* * *$ & $*$-to-N \\
Near to canopy & $* * *$ & $* *$ & $* *$ & $* * *$ & $* * *$ & $* .082$ \\
Far from canopy & $* * *$ & $* * *$ & $*$ & $* * *$ & $* *$ & $* 143$ \\
\hline
\end{tabular}

Note: Rows with the same superscript letters are not significantly different at $P<0.05,{ }^{*}$ are given when $P$ values less than $0.05,{ }^{* *}$ are given when $P$ values less than 0.01 , and ${ }^{* * *}$ are given when $P$ values less than 0.001

OC \% organic carbon percent, Total N\% total nitrogen, Available P (ppm) available phosphorus, EC (dS/m) electrical conductivity, CEC meq/100 g cation exchange capacity 


\section{Discussion}

\section{Impact of $O$. abyssinica and D. melanoxylon on soil} properties

Organic carbon content was significantly $(P<0.05)$ higher under canopies of both trees than the outside canopy. It was higher by $33 \%$ and $57 \%$ under the canopies of the scattered Oxytenanthera abyssinica and Dalbergia melanoxylon tree species, respectively, than an open field. The range of OC content (0.65-1.73\%) in both species is often what is encountered in soils of the semiarid areas, which is $>1 \%$ (Bationo et al. 1993). This finding is in agreement with previous studies in different sites of Ethiopia, where Hailu et al. (2000) reported for Millettia ferruginea, Asfaw and Agren (2007) for Millettia ferruginea and Cordia africana, Kassa et al. (2010) for Balanites aegyptiaca, Manjur et al. (2014) for Faidherbia abida and Croton macrostachyus, Kewessa et al. (2015) for Hypericum revolutum, and Asaye (2017) for Acacia tortilis. This might be related to the higher leaf fall and litter decomposition from the tree species (Asaye and Zewdie 2013).

Total nitrogen was significantly $(P<0.001)$ affected by species and increased with increasing distance from the tree trunk of both species (Table 1). Total nitrogen concentration under the tree canopy of $O x y$ tenanthera abyssinica and Dalbergia melanoxylon was respectively higher by $117 \%$ and $86 \%$ as compared to the far distance canopy. This finding is in agreement with previous studies reported for different area of Ethiopia such as Hailu et al. (2000) for Millettia ferruginea, Yadessa et al. (2001) for Cordia africana, Asfaw and Agren (2007) for Millettia ferruginea and Cordia africana, and Berhe et al. (2013) for Ficus thonningii. This might have been resulted from the high organic matter inputs from fine root degeneration and litterfall followed by microbial activities under tree crowns (Manjur et al. 2014). Taking the average number of trees in parkland agroforestry as 20, if framers retain and/or plant Oxytenanthera abyssinica and Dalbergia melanoxylon tree on their farmland they can respectively save about $23 \%$ and $12 \%$ inorganic fertilizer (urea).

Available phosphorus was significantly $(P<0.001)$ affected by distance from the tree trunk. It showed a decreasing trend with increasing distance from the tree trunk. It was $20 \%$ higher under the canopy of both trees than the open field. A similar study in other parts of Ethiopia such as Hailu et al. (2000) for Millettia ferruginea, Manjur et al. (2014) for Faidherbia albida and Croton macrostachyus tree, Asaye (2017) for Acacia tortilis trees reported higher available phosphorus under the canopy than the open cultivated land. The higher concentration of available phosphorus under the canopy of these tree species was likely due to increased leaf fall and biological activities (Belsky et al. 1989), which might facilitate the release of phosphorus from both organic matter and inorganic sources. Taking the average number of trees in parkland agroforestry as 20, if framers retain and/or plant Oxytenanthera abyssinica and Dalbergia melanoxylon trees on their farmland they can respectively save about $4 \%$ and $3 \%$ inorganic fertilizer (DAP).

EC was lower by $12.5 \%$ and $21.4 \%$ under the tree canopy of Oxytenanthera abysinica and Dalbergia melanoxylon respectively as compared to the open field. The finding of the current study is consistent with that of Berhe et al. (2013) reported for Ficus thonningii in Ahferom district (in Tigray, Ethiopia). The lower soil EC under tree canopies might be due to increased above ground litter accumulation and associated cation uptake by the Oxytenanthera abysinica and Dalbergia melanoxylon trees (Manjur et al. 2014).

The average soil cation exchange capacity was highly significantly $(P<0.001)$ affected by distance from the tree in Oxytenanthera abyssinica but not significantly different in Dalbergia melanoxylon tree. CEC content under both tree canopies was by $24 \%$ higher than that of an open field. A significant increase in soil CEC has also been reported by Hailu et al. (2000), Manjur et al. (2014) and Asaye (2017) in other parts of Ethiopia. This phenomenon could be due to higher organic matter accumulation at the tree bases (Jones 2001). According to these authors, with an increase in organic matter under the canopies of trees, the total negative charge of the soil increases, which in turn increases the CEC of the soil.

The soil $\mathrm{pH}$ values for the within the canopy (6.13) was lower than that of the open field (6.56) for Oxytenanthera abyssinica showing a decrease by $7.02 \%$ (Table 1). Unlike Oxytenanthera abyssinica, there was no significant difference in soil $\mathrm{pH}$ among the three distance zones of Dalbergia melanoxylon tree. According to Marx et al. (1999) and Sanchez et al. (1982), the generally lower soil $\mathrm{pH}$ values under the canopy as compared to open fields might be due to several mechanisms of the trees which release $\mathrm{H}^{+}$ ions, such as soil base cation uptake (or depletion) by the tree, decomposition of organic matter to organic acids and carbon dioxide, root respiration, and nitrification (Rhoades 1996; Ballard 2000).

The C:N ratio under Oxytenanthera abyssinica trees was also lower than that of open field, implying improved availability of $\mathrm{N}$ to plants under the trees. The higher $\mathrm{C}$ to $\mathrm{N}$ ratio also indicates lower $\mathrm{N}$ availability to plants because of increased immobilization of $\mathrm{N}$ by micro-organisms (Handayanto et al. 1997). Results of the present study are in agreement with the findings of 
different authors elsewhere such as Enideg (2008) and Tadesse et al. (2000). For instance, Enideg (2008) reported a $\mathrm{C}$ to $\mathrm{N}$ ratio that increases with increasing distance from Ficus thonninigii. Yet, Hailu et al. (2000) observed lower C to N ratio under Millettia tree than in the open areas for both the surface and the subsurface soils.

\section{Comparison of the impact of $O$. abyssinica and $D$. melanoxylon on soil properties}

The soil OC, TN, AvP, and CEC under the canopy of Oxytenanthera abyssinica were significantly higher by $69 \%, 100 \%, 13 \%$, and $42 \%$, respectively, as compared to that under the canopy of Dalbergia melanoxylon. However, the soil reaction $(\mathrm{pH})$ and EC were significantly lower by $19 \%$ and $57 \%$, respectively, under the canopy of Oxytenanthera abyssinica than Dalbergia melanoxylon. For the $\mathrm{C}$ to $\mathrm{N}$ ratio, there was no significant difference between tree species. The soil OC, TN, AvP, and CEC near to canopy of Oxytenanthera abyssinica were significantly higher by $82 \%, 44 \%, 13 \%$, and $58 \%$, respectively, than that of Dalbergia melanoxylon. However, the soil reaction $(\mathrm{pH})$ and EC were significantly lower by $14 \%$ and $58 \%$, respectively, in near to the canopy of Oxytenanthera abyssinica than that of Dalbergia melanoxylon. The soil OC, TN, AvP, and CEC values for the open field were significantly higher by $100 \%, 71 \%, 13 \%$, and $38 \%$, respectively, than that of Dalbergia melanoxylon. However, the soil reaction $(\mathrm{pH})$ and EC were significantly lower by $9 \%$ and $75 \%$, respectively, in the respective open farm of Oxytenanthera abyssinica than that of Dalbergia melanoxylon.

\section{Conclusions}

Our results revealed that $\mathrm{OC}, \mathrm{AvP}, \mathrm{TN}, \mathrm{CEC}$, and $\mathrm{pH}$ for Oxytenanthera abyssinica and OC, AvP, and TN for Dalberigia melanoxylon were significantly higher under the canopy of the tree as compared to the open field. Hence, the management/growing of Oxytenanthera abyssinica and Dalberigia melanoxylon trees on small holder farms improve soil fertility. As compared to Dalbergia melanoxylon, Oxytenanthera abyssinica had a significantly higher contribution to soil property enhancement. Hence, retaining these species and in particular Oxytenanthera abyssinica on farms in the study area and elsewhere having similar biophysical profile is of paramount importance for soil fertility enhancement so as to improve food security of small farming households. Moreover, further study on soil microbial population associated with Oxytenanthera abyssinica and Dalberigia melanoxylon trees such as mycorrhizae and rhizobial associations and rooting systems is needed.

\section{Acknowledgements}

The authors acknowledge the financial support from Tigray Agricultural Research Institute (Humera Agricultural Research Center) and technical support from Mekelle University. We are grateful to the two anonymous referees for constructive comments on an earlier version of this manuscript.

\section{Authors' contributions}

$Y G, K T, T G$, and $E B$ designed the study. $Y G$ conducted the laboratory experiment. $Y G$ and $K T$ analyzed the data. $Y G, K T, T G, S T, E B, G E$, and EM wrote the manuscript. All authors read and approved the final manuscript.

\section{Funding}

The funders had no role in study design, data collection, and analysis, decision to publish, or preparation of the manuscript.

Availability of data and materials

Please contact the author for data requests.

Ethics approval and consent to participate

Not applicable

Consent for publication

Not applicable

\section{Competing interests}

The authors declare that they have no competing interests.

\section{Author details}

'Humera Agricultural Research Center (HuARC), Tigray Agricultural Research Institute (TARI), P.O. Box 62, Humera, Ethiopia. '2Department of Land Resources Management and Environmental Protection, Mekelle University, P.O. Box 231, Mekelle, Ethiopia. ${ }^{3}$ Ministry of Environment, Forest and Climate Change of Ethiopia, Addis Ababa, Ethiopia. ${ }^{4}$ Faculty of Environmental Sciences and Natural Resource Management, Norwegian University of Life Sciences, PO Box 5003, No-1432 Ås, Norway. ${ }^{5}$ Mekelle Agricultural Research Center (MARC), Tigray Agricultural Research Institute (TARI), P.O. Box 258, Mekelle, Ethiopia.

Received: 8 April 2019 Accepted: 5 August 2019

Published online: 05 September 2019

\section{References}

Ajake AO (2013) The role of forest trees in indigenous farming systems as a catalyst for forest resources management in the rural villages of Cross River State, Nigeria. Glob J Hum Soc Sci Res 12(13): https://globaljournals.org/ GJHSS Volume12/2-The-Role-of-Forest-Trees-in-Indigenous.pdf.

Akinnifesi FK, Ajayi OC, Sileshi G, Chirwa PW, Chianu J (2010) Fertiliser trees for sustainable food security in the maize-based production systems of East and Southern Africa. A review. Agron Sustain Dev 30(3):615-629

Aladi SF, John OO (2014) Farmers perception of opportunities preferences and obstacles of growing multipurpose trees on farmland in Kogi State. Eur Sci J 10(14):607-617

Asaye Z (2017) Effects of scattered Acacia tortilis (Forssk) hayne on soil properties in different land uses in Central Rift Valley of Ethiopia. J Sustain For 36(2): 164-176

Asaye Z, Zewdie S (2013) Fine root dynamics and soil carbon accretion under thinned and un-thinned Cupressus lusitanica stands in, Southern Ethiopia. Plant Soil 366(1-2):261-271

Asfaw Z, Agren GI (2007) Farmers' local knowledge and topsoil properties of agroforestry practices in Sidama, Southern Ethiopia. Agrofor Syst 71(1):35-48

Ballard T (2000) Impacts of forest management on northern forest soils. For Ecol Manag 133(1):37-42

Bationo A, Christianson CB, Klaij MC (1993) The effect of crop residue and fertilizer on pearl millet yields in Niger. Fertilizer Res 34:251-258

Bationo A, Waswa B, Kihara J, Kimetu J (2007) Advances in integrated soil fertility management in sub-Saharan Africa: challenges and opportunities. Nutr Cycl Agroecosyst 76(2-3):1-2

Bein E, Habte B, Jaber A, Birnie A, \& Tengnäs B (1996) Useful trees and shrubs in Eritrea: identification, propagation and management for agricultural and 
pastoral communities. Technical handbook (12) ICRAF Project, World Agroforestry Centre, Eastern Africa Region: Nirobi. 422p

Bekele-Tesemma A (2007) Useful trees and shrubs of Ethiopia: identification, propagation, and management for 17 agroclimatic zones. RELMA in ICRAF Project, World Agroforestry Centre, Eastern Africa Region, Nirobi, p 552

Belsky A, Amundson R, Duxbury J, Riha S, Ali A, Mwonga S (1989) The effects of trees on their physical, chemical and biological environments in a semi-arid savanna in Kenya. J Appl Ecol 26(3):1005-1024.

Berhe DH, Anjulo A, Abdelkadir A, Edwards S (2013) Evaluation of the effect of Ficus thonningii (Blume) on soil physicochemical properties in Ahferom district of Tigray, Ethiopia. J Soil Sci Environ Manag 4(2):35-45

Bishaw B (2001) Deforestation and land degradation in the Ethiopian highlands: a strategy for physical recovery. Northeast Afr Dev Arch Paper 2. http:// scholarworks.wmich.edu/africancenter_icad_archive/2.

Bystriakova N, Kapos V, \& Igor L (2004) Bamboo biodiversity: Africa, Madagascar and the Americas. UNEP CMC/INBAR. UNEP World Conservation Monitoring Centre, Cambridge, UK International Network for Bamboo and Rattan. Beijing, $90 \mathrm{pp}$.

Chesworth W (2008) Encyclopedia of soil science, 1st edn. Netherland, Springer

Enideg D (2008) Importance of Ficus thonningii Blume in soil fertility improvement and animal nutrition in Gondar Zuria, Ethiopia. M.Sc. Thesis, University of Natural Resources and Applied Life Science, Vienna

FAO (2006) Guidelines for soil description, 4th edn. Food and Agriculture Organization of the United Nations, Rome

Gebrewahid Y, Gebre-Egziabhier T, Teka K, Birhane E (2018) Carbon stock potential of scattered trees on farmland along an altitudinal gradient in Tigray, Northern Ethiopia. Ecol Process 7(1):40

Gindaba J, Rozanov A, Negash L (2005) Trees on farms and their contribution to soil fertility parameters in Badessa, eastern Ethiopia. Biol Fertil Soils 42(1):66-71

Gladwin CH, Peterson JS, Uttaro R (2002) Agroforestry innovations in Africa: can they improve soil fertility on women farmers' fields. Afr Stud Q 6:245-269

Hailu T, Negash L, Olsson M (2000) Millettia ferruginea from southern Ethiopia: impacts on soil fertility and growth of maize. Agrofor Syst 48(1):9-24

Handayanto E, Cadisch G, Giller KE (1997) Regulating N-mineralization from plant residues by manipulation of quality. In: Cadisch G, Giller KE (eds) Driven by nature: plant litter quality and decomposition. CAB International, pp 175-185 CAB International. http://agris.fao.org/agris-search/search.do?recordID=US2 01302873290

Houba V, Vander L, Novazamsky I, Walinga I (1989) Plant and soil analysis procedures. Department of Soil Science and Plant Nutrition Agric. Univ, Wageningen

Jackson M (1958) Soil chemical analysis, 6th edn. Prentice; Halls, Inc., Englewood Cliffs, New Jersey, p 498

Jackson N (2000) Measured and modelled rainfall interception loss from an agroforestry system in Kenya. Agric For Meteorol 100(4):323-336

Jones JB (2001) Laboratory guide for conducting soil tests and plant analysis. CRC Press, Boca Raton, p 142

Kamara C, Haque I (1992) Faidherbia albida and its effects on Ethiopian highland vertisols. Agrofor Syst 18(1):17-29

Kassa H, Gebrehiwet K, Yamoah C (2010) Balanites aegyptiaca, a potential tree for parkland agroforestry systems with sorghum in Northern Ethiopia. J Soil Sci Environ Manag 1(6):107-114

Kewessa G, Tiki L, Molla A (2015) Effects of Hypericum revolutum (Vahl) tree on major soil nutrients and selected soil physico-chemical properties in Goba District, Oromia, Ethiopia. Wudpecker J Agric Res 4(1):6-13

Manjur B, Abebe T, Abdulkadi A (2014) Effects of scattered F. albida (Del) and C. macrostachyus (Lam) tree species on key soil physicochemical properties and grain yield of maize (Zea mays): a case study at umbulo Wacho watershed. Southern Ethiop J Agric Res 3(3):063-073

Marx ES, Hart J, Stevens RG (1999) Soil test interpretation guide. Oregon State Extension Service, p 7. https://ir.library.oregonstate.edu/downloads/ w9505065q.

McLean EO (1982). Soil pH and lime requirement. In: Page AL, Miller LH, Keeney DR (Eds.), Methods of soil analysis. Part 2. Chemical and microbiological properties, Agronomy Monograph 2nd ed., vol. 9, American Society of Agronomy, Madison, 199-224

Morris M, Kelly VA, Kopicki RJ, Byerlee D (2007) Fertilizer use in African agriculture. Lessons learned and good practice guidelines. The World Bank, Washington, DC
Mosquera-Losada M, McAdam J, Romero-Franco R, Santiago-Freijanes JJ, \& Rigueiro-Rodróguez A (2009). Definitions and components of agroforestry practices in Europe. In: Rigueiro-Rodríguez A, McAdam J, Mosquera-Losada MR (eds.) Agroforestry in Europe, vol 6. Springer, Dordrecht

Ogunkunle C, Awotoye O (2010) Soil fertility status under different tree cropping system in a southwestern zone of Nigeria. Notulae Scientia Biologicae, 3(2): 123-128.

Olsen SR, \& Sommers LE (1982). Phosphorus. In: Page AL, Miller LH, Keeney DR (Eds.), Methods of soil analysis. Part 2. Chemical and microbiological properties, Agronomy Monograph 2nd ed., vol. 9, American Society of Agronomy, Madison, 403-430

Pandey, C.B., Singh, A.K. and Sharma, D.K., 2000. Soil properties under Acacia nilotica trees in a traditional agroforestry system in central India. Agroforestry systems, 49(1), pp. 53-61.

Rhoades C (1996) Single-tree influences on soil properties in agroforestry: lessons from natural forest and savanna ecosystems. Agrofor Syst 35(1):71-94

Ritter E, Dalsgaard L, Einhorn KS (2005) Light, temperature and soil moisture regimes following gap formation in a semi-natural beech dominated forest in Denmark. For Ecol Manag 206(1-3):15-33

Rosenstock T, Tully K, Arias-Navarro C, Neufeldt H, Butterbach-Bahl K, Verchot L (2014) Agroforestry with $N_{2}$-fixing trees: sustainable development's friend or foe? Curr Opin Environ Sustain 6:15-21

Sanchez PA, Couto W, Boul SW (1982) The fertility capability soil classification system: interpretation, applicability and modification. Geoderma 27:283-309

Sanchez PA, Swaminathan M (2005) Hunger in Africa: the link between unhealthy people and unhealthy soils. Lancet 365:442-444

Shukla PK (2009) Nutrient dynamics of tea plantations and their impact on soil productivity - a case study from India. Proceedings of the 8th World Forestry Congress, Oct. 18-23, Buenos Aires, Argentina, pp 1-11

Sisay M, Mekonnen K (2013) Tree and shrub species integration in the croplivestock farming system. Afr Crop Sci J 21(1):647-656

Wang X (2006) Comparative analysis and policy recommendations on developing bamboo resource tenure systems in Asia and Africa. Joint Project in Cooperation with INBAR and WFI

Yadessa A, Itanna F, Olsson MR (2001) Contribution of indigenous trees to soil properties: the case of scattered trees of Cordia africana Lam. in croplands of western Oromia. Ethiop J Nat Resour 3(2):245-270

\section{Publisher's Note}

Springer Nature remains neutral with regard to jurisdictional claims in published maps and institutional affiliations.

\section{Submit your manuscript to a SpringerOpen ${ }^{\circ}$ journal and benefit from:}

- Convenient online submission

- Rigorous peer review

- Open access: articles freely available online

High visibility within the field

- Retaining the copyright to your article

Submit your next manuscript at $>$ springeropen.com 